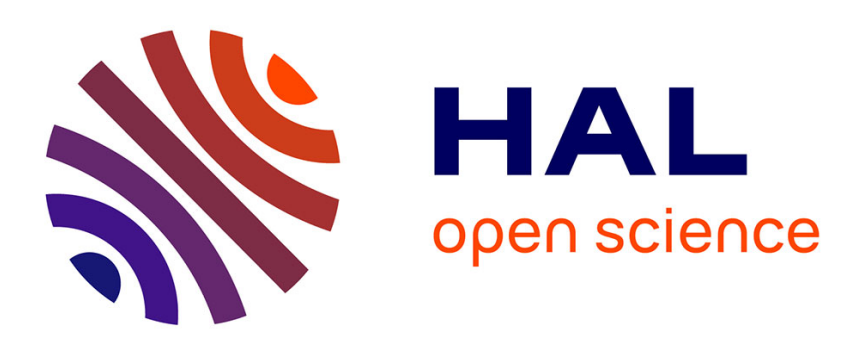

\title{
Foot biomechanical modelling to study orthoses influence
}

Vincent Luboz, Antoine Perrier, Nicolas Vuillerme, Marek Bucki, Bruno Diot, Francis Cannard, Yohan Payan

\section{- To cite this version:}

Vincent Luboz, Antoine Perrier, Nicolas Vuillerme, Marek Bucki, Bruno Diot, et al.. Foot biomechanical modelling to study orthoses influence. Computer Methods in Biomechanics and Biomedical Engineering, 2012, 15 (S1), pp.360-362. 10.1080/10255842.2012.713689 . hal-00738396

\section{HAL Id: hal-00738396 https://hal.science/hal-00738396}

Submitted on 5 Oct 2012

HAL is a multi-disciplinary open access archive for the deposit and dissemination of scientific research documents, whether they are published or not. The documents may come from teaching and research institutions in France or abroad, or from public or private research centers.
L'archive ouverte pluridisciplinaire HAL, est destinée au dépôt et à la diffusion de documents scientifiques de niveau recherche, publiés ou non, émanant des établissements d'enseignement et de recherche français ou étrangers, des laboratoires publics ou privés. 


\title{
Foot Biomechanical Modeling to Study Orthoses Influence
}

\author{
V. LUBOZ* ${ }^{1}$, A. PERRIER ${ }^{123}$, N. VUILLERME ${ }^{2}$, M. BUCKI ${ }^{13}$, B. DIOT ${ }^{4}$, F. CANNARD $^{3}$ and \\ Y. PAYAN ${ }^{1}$ \\ ${ }^{1}$ TIMC Laboratory, CNRS-UJF, 38706 La Tronche, France \\ ${ }^{2}$ AGIM Laboratory, CNRS-UJF-UPMF-EPHE, 38706 La Tronche, France \\ ${ }^{3}$ TexiSense, Montceau-les-Mines, France, $\quad{ }^{4}$ IDS, Montceau-les-Mines, France.
}

Keywords: Biomechanical modeling, Patient-specific models, Finite Element Method, Orthosis design.

\section{Introduction}

Several pathologies of the foot can be solved simply by adding an orthosis under the patient's foot. Defining the geometry and the size of such orthosis is key in optimizing its influence on the foot. For example, an orthosis with a heel lift (HL) has an increased height below the heel to force the patient to put his weight on front of the foot. An orthosis with a metatarsal bar associated with under capital extension of the 1st ray (BAR) has a bump going across the insole and placed below the front of the arch to stabilize the first metatarsal bones and to release the pressure under their heads. Unfortunately, most of the orthoses produced today are not specifically design for a patient. They allow improvements to some degrees but could be more efficient if they were patient specific. We propose to use a patient-specific finite element (FE) foot model to study the influence of such orthoses and to help designing them in a better way, in accordance with the patient's anatomy and pathology.

\section{Methods}

The FE foot model has been developed using the 3D biomechanical simulation platform, Artisynth (http://www.artisynth.org/). The model is composed of soft tissues, bones and joints, Figure 1. The soft tissues represent the muscles, tendons, ligaments and fat and are combined in a FE mesh using a nearly-incompressible linear elastic material which properties are derived from measurements with LASTIC [1] (based on pipette aspiration principle) on a healthy subject: a Young modulus of $175 \mathrm{kPa}$ and a Poisson ration of 0.49 . Half of the subject's weight is considered to be on the foot: $40 \mathrm{~kg}$. Each of the 28 foot bone segments (including tibia and fibula) is modeled as a solid body surface and is rigidly coupled to the soft tissues. The joints are simulated by cylindrical pivots connecting each bone with its neighbors. As a real joint, the angle they allow between each bone is constrained.

Four orthoses were considered in this study: HL, BAR, with retro capital bar (RCB), and with medial heel skive (MHS), Figure 2. Compared to the BAR orthosis, the RCB does not have an under capital extension of the 1st ray. The MHS insole is similar to the HL one, but with a longer bump under the arch of the foot. Each insole is modeled as a fixed solid body over which the foot model is laid, while submitted to gravity.

When the foot finite elements enter in contact with the orthosis, a pressure appears at the surface of the soft tissues. This pressure is propagated through the FE material up to the bones which in turn propagate the pressure in the whole foot via the joints connecting the bones. The mechanical influence of the orthosis can therefore be analyzed.

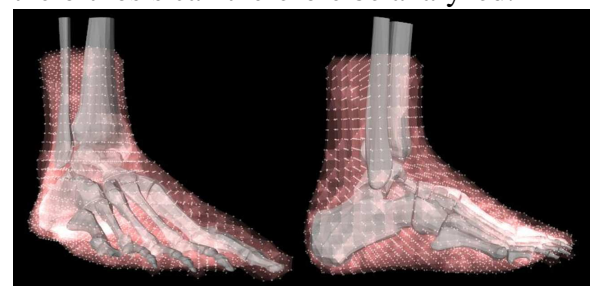

Figure 1. The finite element model of the foot soft tissue and the solid bodies representing the bones.

Applying our Mesh Matching algorithm [2] to this foot model and to patients' medical datasets (such as CT scans), new models, including the FE model and the bony structures, can be created and can undergo FE simulation in Artisynth. This allows to perform a patient specific study of the influence of the different orthoses and potentially to choose which is the most appropriate for a patient.

\section{Results and Discussion}

Figure 2 shows the pressure maps corresponding to the contact between each of the four orthoses and the sole of the foot. Table 1 summarizes the pressures observed under the foot under the heel, on the skin under the third metatarsal head, and at the metatarsal interface with the soft tissue.

As expected, the highest pressure is monitored under the heel, because of the subject's weight. Nevertheless variations of pressure amplitude can be observed depending on the orthoses. For the BAR and RCB orthoses, the pressure is reduced under the head of the metatarsal bones, at the arch extremity near the toes. On the other hand, the MHS and HL insoles increase pressure at the front of the foot because of the weight transfer.

With a maximum pressure around $90 \mathrm{kPa}$, the orthoses apply a similar pressure on the foot heel. 
This is coherent with the pressure of $150 \mathrm{kPa}$ measured by [3] on 80 patient and reported by [4]. This highest pressure is reasonable because of the subject's weight. Furthermore, a reduction can be observed for the MHS and HL orthoses as could be expected by their design which release the load on the heel to put the patient's mass on the toes, which also increase as can be seen in Table 1. The HL orthosis creates a smaller shift of the weight since it is lower and flatter than the MHS.

A similar analysis can be undertaken for the BAR and RCB orthoses because they have the same bump under the arch, reducing the pressure under the metatarsal bones' heads. The only difference is the RCB extension which leads to a greater pressure reduction under the metatarsal heads, Table 1.

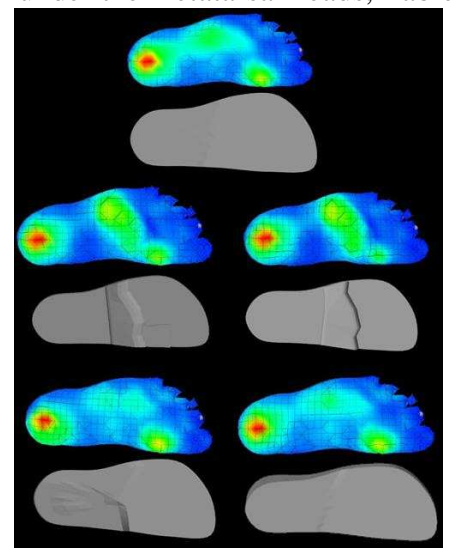

Figure 2. Pressure map of the foot sole (darker colors mean less pressure, red is close to $100 \mathrm{kPa}$ ), lines 1, 3 and 5. A flat insole (line 2) and the four different orthoses, from left to right: BAR, RCB, MHS and HL, lines 4 and 6.

Because our model assigns the same linear elastic material to the muscles, the fat, the tendons and ligaments of the foot, some errors are inevitably introduced in the simulations. Nevertheless, the current model already allows studying with a satisfactory precision the internal foot pressures because of the complex interactions between the soft tissues, the bones and the joints.

\section{Conclusions}

This paper introduces a biomechanical model of the foot, simulating its soft tissues as an elastic linear material and its bones as rigid structures. It improves the state of the art by adding realistic joint constraints. The pressures measured under the foot with four different orthoses are realistic in terms of position and orders of magnitude. This enhanced anatomical modeling hence enables the study of the different orthoses influence on the patient anatomy. Future work will aim at separating the different components of the foot soft tissues. We are currently differentiating the ligaments from the rest of the soft tissues to add their influence to the model and to allow simulating the tensions they generate during the different pressure applications. Having different layers and materials for the muscles and the fat tissues could improve the precision of the simulation by matching the foot anatomy more closely. We also aim at integrating nonlinear modeling for these soft tissues as presented in [5] where our foot model was used for the prediction of ulcer formation. Indeed, this patient-specific FE foot model will be coupled with a "smart sock" which textile is able to measure pressure around the foot. The idea is to alert the person (especially diabetic patient) when an internal overpressure is observed and may create an ulcer.

\begin{tabular}{|c|c|c|c|c|c|}
\hline Orthosis & FLAT & $\mathrm{BAR}$ & $\mathrm{RCB}$ & $\mathrm{MHS}$ & $\mathrm{HL}$ \\
\hline Heel & 92 & 88 & 89 & 86 & 91 \\
Pressure & $\mathrm{kPa}$ & $\mathrm{kPa}$ & $\mathrm{kPa}$ & $\mathrm{kPa}$ & $\mathrm{kPa}$ \\
\hline Meta. skin & 19 & 10.5 & 6.3 & 20 & 18.5 \\
pressure & $\mathrm{kPa}$ & $\mathrm{kPa}$ & $\mathrm{kPa}$ & $\mathrm{kPa}$ & $\mathrm{kPa}$ \\
\hline Meta. int. & 32 & 30.5 & 20 & 36 & 34 \\
pressure & $\mathrm{kPa}$ & $\mathrm{kPa}$ & $\mathrm{kPa}$ & $\mathrm{kPa}$ & $\mathrm{kPa}$ \\
\hline
\end{tabular}

Table 1. Maximum pressures measured under the heel, at the metatarsal surface (skin) and internally when laid on the four different orthoses.

\section{References}

[1] Schiavone P, Promayon E, Payan Y. LASTIC: A Light Aspiration Device for in vivo Soft TIssue Characterization. ISBMS, 5958:110,2010

[2] Bucki M., Lobos C., Payan Y. A Fast and Robust Patient Specific Finite Element Mesh Registration Technique: Application to 60 Clinical Cases. Med. Im. An., 14:303-317, 2010.

[3] Cavelius M, Cunin C, Denouvion L, Depaifve C. Étude des pressions sous les têtes métatarsiennes. Rev. Podol., 7(42):15-18, 2011.

[4] Chen WM, Lee T, Vee-Sin Lee P, Lee JW, Lee SJ. Effects of internal stress concentrations in plantar soft-tissue preliminary three-dimensional finite element analysis. Med. Eng. \& Phys. 32, 324-331, 2010.

[5] Luboz V, Bucki M, Stavness I, Cannard F, Payan Y. The Biomechanical modeling of the foot to study and Prevent the formation of ulcers. European Society of Biomechanics Conference, 2012.

\section{Acknowledgments}

The authors wish to thank the ANR TecSan IDS project for their financial support. 